Review

\title{
Emerging Biological Treatments for Uterine Cervical Carcinoma
}

\author{
Patrizia Vici ${ }^{\bowtie}$, Luciano Mariani2,3, Laura Pizzuti ${ }^{1}$, Domenico Sergi1 ${ }^{1}$, Luigi Di Lauro ${ }^{1}$, Enrico Vizza ${ }^{2}$, Fed- \\ erica Tomao ${ }^{4}$, Silverio Tomao ${ }^{5}$, Emanuela Mancini² ${ }^{2}$, Cristina Vincenzoni² ${ }^{2}$ Maddalena Barba1 ${ }^{1,6}$, Marcello \\ Maugeri-Saccà ${ }^{1,6}$, Giuseppe Giovinazzo ${ }^{7}$, Aldo Venuti ${ }^{3,8}$ \\ 1. Department of Medical Oncology B, Regina Elena National Cancer Institute, V Elio Chianesi 53, 00144, Rome, Italy \\ 2. Department of Gynecologic Oncology, Regina Elena National Cancer Institute, V Elio Chianesi 53, 00144, Rome, Italy \\ 3. HPV Unit, Regina Elena National Cancer Institute, V Elio Chianesi 53, 00144, Rome, Italy \\ 4. Department of Gynaecology and Obstetrics, "La Sapienza" University, V Policlinico 155, 00161, Rome, Italy \\ 5. Department of Medical-Surgical Sciences and Biotechnologies, “La Sapienza” University of Rome, Oncology Unit, C.so della Repubblica, 04100, \\ Latina, Italy \\ 6. Scientific Direction, Regina Elena National Cancer Institute, V Elio Chianesi 53, 00144, Rome, Italy \\ 7. Department of Radiation Oncology, Regina Elena National Cancer Institute,V Elio Chianesi 53, 00144, Rome, Italy \\ 8. Laboratory of Virology, Regina Elena National Cancer Institute, V Elio Chianesi 53, 00144, Rome, Italy
}

$\square$ Corresponding author: Patrizia Vici, MD, Department of Medical Oncology B - Regina Elena National Cancer Institute, V Elio Chianesi 53, 00144, Rome, Italy. E-mail: pvici@ifo.it; Tel.: $00390652665584 ;$ Fax: 00390652665075

() Ivyspring International Publisher. This is an open-access article distributed under the terms of the Creative Commons License (http://creativecommons.org/ licenses/by-nc-nd/3.0/). Reproduction is permitted for personal, noncommercial use, provided that the article is in whole, unmodified, and properly cited.

Received: 2013.10.23; Accepted: 2013.12.09; Published: 2014.01.05

\begin{abstract}
Cervical cancer is the third most common cancer worldwide, and the development of new diagnosis, prognostic, and treatment strategies is a major interest for public health. Cisplatin, in combination with external beam irradiation for locally advanced disease, or as monotherapy for recurrent/metastatic disease, has been the cornerstone of treatment for more than two decades. Other investigated cytotoxic therapies include paclitaxel, ifosfamide and topotecan, as single agents or in combination, revealing unsatisfactory results. In recent years, much effort has been made towards evaluating new drugs and developing innovative therapies to treat cervical cancer. Among the most investigated molecular targets are epidermal growth factor receptor and vascular endothelial growth factor (VEGF) signaling pathways, both playing a critical role in cervical cancer development. Studies with bevacizumab or VEGF receptor tyrosine kinase have given encouraging results in terms of clinical efficacy, without adding significant toxicity. A great number of other molecular agents targeting critical pathways in cervical malignant transformation are being evaluated in preclinical and clinical trials, reporting preliminary promising data.

In the current review, we discuss novel therapeutic strategies which are being investigated for the treatment of advanced cervical cancer.
\end{abstract}

Key words: advanced cervical cancer, therapy, clinical trials, molecular targeted agents, tyrosine kinase inhibitors.

\section{INTRODUCTION}

Cervical cancer incidence and mortality in the developed world have declined over the past 3 decades, but it is still the fourth leading cause of death in females worldwide and the second leading cause of mortality among women aged 19-39 years [1]. Up to $35 \%$ of patients with locally advanced cervical cancer previously treated with surgery or radiation will develop persistent/recurrent/metastatic disease, where platinum-based chemotherapy still represents the gold standard treatment [2]. Although other agents, including paclitaxel, ifosfamide and topotecan, have been investigated as single agents or in combination, 
responses are often unsatisfactory and of short duration, thus optimal medical treatment in such unfavourable patient subset has to be defined. The development of innovative and effective therapies in advanced and refractory cervical cancer remains a high priority, and research is needed to elucidate new targets for therapy, also based on scientific rationale of viral carcinogenesis.

Human papillomavirus (HPV) infection is considered the necessary cause of cervical cancer, as more than $96 \%$ of cervical cancers are positive for high-risk HPV viruses, especially type 16, the most predominant type identified in precancerous lesions and in cervical cancer. Other high risk HPV types, such as 18, 31, 33, 35 are, even less frequently, involved in HPV related carcinogenesis from high-grade cervical intraepithelial neoplasia (CIN) to invasive carcinoma [3]. Malignant transformation by HPV is primarily related to 3 oncoproteins: E5, E6, E7. In cervical cancer E6 and E7 genes are consistently expressed, and mediate malignant transformation through degradation of p53 and inactivation of retinoblastoma $(\mathrm{Rb})$ tumor suppressor proteins, respectively [4]. After genomic virus integration, dysregulation of p53 tumor suppressor gene is mediated by E6 through 2 different mechanisms. The first one involves blocking induction of p53 following DNA damage, which normally drive to DNA repair or to cell apoptosis. The second mechanism involves E6-induced p53 ubiquitination and degradation through its association with another protein, E6-AP, a component of the ubiquitin proteolytic pathway, and induces cell proliferation by dysruptin p53 and by targeting the expression of other apoptotic proteins. E7 exerts its oncogenic effects primarily by binding with retinoblastoma protein $(\mathrm{pRb})$, and with other proteins, (p107, p130), which regulate cell proliferation. The binding with $\mathrm{pRb}$ results in proteasomal degradation of $\mathrm{pRb}$ and unrestricted transcriptional activity, so maintaining epithelial cells ready to enter phase $S$ of cycle, leading to cell cycle deregulation $[5,6]$, and resulting genomic instability. The role of E5 is less well defined. It is considered as an oncogene cooperating with E6/E7 in the early stages of cervical carcinogenesis, while in invasive cancers E5 is expressed in tumors which contain the episomal viral genome. E5, E6 and E7 have complex interactions with many growth factor signalling pathways, angiogenesis, inflammation and apoptotic response, abrogate cell cycle checkpoints and induce genomic instability leading to malignant transformation $[3,7]$. After viral integration, E6/E7 becomes constitutively expressed [8], and exert their functions. The integration of HPV virus with the host genome blocks the productive life cell cycle, determines immortalization and favours acquisition of additional mutations required for malignant transformation along with escaping immune control.

In the last decades, scientific efforts on cervical cancerogenesis have mainly focused on analysing the HPV oncoproteins, and in establishing their role in the transformation process. The most relevant results, in terms of primary and secondary prevention, include developing a prophylactic vaccine and HPV-based screening tests, respectively. However, the huge cascade of biological events and biomolecular pathways following the HPV-host interaction remains largely to be analysed. The understanding of these events is highly relevant from the clinical perspective, in order to identify innovative and more targeted pharmacological treatments.

The current review outlines the existing and emerging preclinical and clinical data concerning new agents targeting the most relevant pathways involved in cervical cancer development/progression. Table 1 reports the results of the main clinical trials with biological agents in advanced cervical cancer and Table 2 shows the most relevant ongoing clinical trials.

\section{ANTI-ANGIOGENETIC AGENTS}

Overexpression of the vascular endothelial growth factor (VEGF) family proteins is associated with poor prognosis in many cancers, including squamous and adenocarcinomas of the cervix, and usually correlates with advanced stages and lymph node metastases [9-11]. Reports show a correlation between elevated serum VEGF levels and poor response/progression free survival (PFS) $[12,13]$. The mechanism involved in tumor-related neoangiogenesis in cervical cancer is driven by persistent HPV infection. p53 downregulation by HPV E6 oncoproprotein increases angiogenic potential through the induction of a series of pro-angiogenetic pathways, including up-regulation of VEGF [14]. Moreover, E6 enhances induction of hypoxia-inducibile factor-1a (HIF-1a), usually associated with poor prognosis, with increased VEGF [15]. It has been reported that E5 induces VEGF expression in cell lines, which involves EGFR phosphorylation, thus resulting in activation of MEK-extracellular signal-regulated kinase $1 / 2$ (ERK1/2) and phosphatidylinositol 3-kinase (PI3K)-Akt pathways [16]; these two pathways regulate VEGF expression through changes in its transcriptional activity. Cox-2-prostaglandin (PG) E2 pathway is also involved in VEGF expression by E5 [17]. Complex interactions occur among VEGF pathway and several growth factors, including epidermal growth factor receptor (EGFR) [18,19], and other pathways involving receptor tyrosine kinases (RTKs) have also been implicated in the development and progression of cervical cancer. 
Table I. Preliminary results of clinical trials of targeted agents in cervical cancer.

\begin{tabular}{|c|c|c|c|c|c|c|}
\hline $\begin{array}{l}\text { First author, year } \\
\text { of publication }\end{array}$ & $\begin{array}{l}\text { Pts } \\
\text { enrolled }\end{array}$ & Phase & Target & Regimen & Clinical endopoint/ORR & Toxicity \\
\hline Tewari., 201323 & 450 & III & VEGF & $\begin{array}{l}\text { Bevacizumab }(15 \mathrm{mg} / \mathrm{kg} \text { iv every } \\
21 \text { days) with or without four } \\
\text { chemotherapy regimens }\end{array}$ & $\begin{array}{l}\text { OS } 17 \text { months in bevacizumab } \\
\text { arms versus } 13 \text { months in the } \\
\text { chemotherapy arms }\end{array}$ & $\begin{array}{l}\text { Treatment with B was associated with } \\
\text { more grade } 3-4 \text { bleeding ( } 5 \text { vs } 1 \% \text { ) } \\
\text { thrombosis/embolism ( } 9 \text { vs } 2 \% \text { ), and GI } \\
\text { fistula ( } 3 \text { vs } 0 \% \text { ). }\end{array}$ \\
\hline Schefter, 201224 & 60 & II & VEGF & $\begin{array}{l}\text { Bevacizumab }(10 \mathrm{mg} / \mathrm{kg} \text { iv every } \\
2 \text { weeks for three cycles) in } \\
\text { combination with definitive } \\
\text { radiotherapy and cisplatin } \\
\text { chemotherapy }\end{array}$ & No data & $\begin{array}{l}15(31 \%) \text { protocol-specified treat- } \\
\text { ment-related AEs within } 90 \text { days of } \\
\text { treatment start; the most common were } \\
\text { hematologic }(12 / 15 ; 80 \%) \text {. No treat- } \\
\text { ment-related SAEs. }\end{array}$ \\
\hline Zighelboim, 201325 & 27 & II & VEGF & $\begin{array}{l}\text { Bevacizumab }(15 \mathrm{mg} / \mathrm{kg} \text { iv every } \\
21 \text { days) with topotecan and } \\
\text { cisplatin }\end{array}$ & ORR: $33.3 \%$ & $\begin{array}{l}\text { Grade } 3-4 \text { hematologic toxicity was } \\
\text { common (thrombocytopenia } 82 \% \text { leu- } \\
\text { kopenia } 74 \% \text {, anemia } 63 \% \text {, neutropenia } \\
56 \% \text { ). Most patients ( } 78 \% \text { ) required } \\
\text { unanticipated hospital admissions for } \\
\text { supportive care and/or management of } \\
\text { toxicities }\end{array}$ \\
\hline Mackay, 201026 & 19 & II & VEGF & Sunitinib $50 \mathrm{mg}$ daily per os & $\begin{array}{l}\text { No objective responses. Median } \\
\text { TTP: } 3.5 \text { months. }\end{array}$ & High rate of fistula development $(26 \%)$ \\
\hline Goncalves, $2008^{44}$ & 30 & II & EGFR & Gefitinib $500 \mathrm{mg}$ daily per os & $\begin{array}{l}\text { No objective responses, six }(20 \%) \\
\text { patients experienced stable } \\
\text { disease with a median duration } \\
\text { of } 111.5 \text { days. Median TTP was } \\
37 \text { days and median OS was } 107 \\
\text { days. }\end{array}$ & $\begin{array}{l}\text { Gefitinib was well tolerated, the most } \\
\text { common drug-related AEs were diar- } \\
\text { rhea, acne, vomiting, and nausea. No } \\
\text { grade } 4 \text { events. }\end{array}$ \\
\hline Schilder, 200947 & 28 & II & EGFR & Erlotinib $150 \mathrm{mg}$ daily per os & $\begin{array}{l}\text { No objective responses with four } \\
(16 \%) \text { achieving } \\
\text { stable disease; only one patient } \\
\text { had a PFS } \geq 6 \text { months }(4 \%) \text {. }\end{array}$ & $\begin{array}{l}\text { Grade } 3 \text { related toxicities included } \\
\text { diarrhea, nausea, emesis, dehydration } \\
\text { and anorexia. One patient experienced } \\
\text { grade } 4 \text { renal toxicity. }\end{array}$ \\
\hline Santin, 201153 & 38 & II & EGFR & $\begin{array}{l}\text { Cetuximab } 400 \mathrm{mg} / \mathrm{m} 2 \text { i.v. initial } \\
\text { dose followed by } 250 \mathrm{mg} / \mathrm{m} 2 \\
\text { weekly }\end{array}$ & $\begin{array}{l}\text { No objective responses with five } \\
\text { patients }(14.3 \%) \text { survived with- } \\
\text { out progression for at least } 6 \\
\text { months. Median PFS and OS } \\
\text { times were } 1.97 \text { and } 6.7 \text { months, } \\
\text { respectively. }\end{array}$ & $\begin{array}{l}\text { Grade } 3 \text { adverse events at least possibly } \\
\text { related to cetuximab included derma- } \\
\text { tologic events, GI, anemia, constitution- } \\
\text { al symptoms, infection, vascular events, } \\
\text { pain, and pulmonary, neurological, } \\
\text { vomiting and metabolic events. No } \\
\text { grade } 4 \text { events }\end{array}$ \\
\hline Tinker, 201386 & 38 & II & mTor & $\begin{array}{l}\text { Temsirolimus ( } 25 \mathrm{mg} \text { i.v. weekly } \\
\text { in } 4 \text { week cycles), }\end{array}$ & $\begin{array}{l}\text { One patient experienced a partial } \\
\text { response }(3.0 \%) .57 .6 \% \text { stable } \\
\text { disease. Median PFS: } \\
\text { 3.52months. }\end{array}$ & $\begin{array}{l}\text { No toxicity grade } 3 / 4 \text { observed. Ad- } \\
\text { verse effects were mild-moderate in } \\
\text { most cases and similar to other temsiro- } \\
\text { limus studies. }\end{array}$ \\
\hline Coronel, 2011100 & 36 & III, R & HDAC & $\begin{array}{l}\text { Hydralazine and valproate (HV) } \\
\text { added to cisplatin topotecan } \\
\text { (hydralazine at } 182 \mathrm{mg} \text { for rapid, } \\
\text { or } 83 \mathrm{mg} \text { for slow acetylators, } \\
\text { and valproate at } 30 \mathrm{mg} / \mathrm{kg} \text {, } \\
\text { beginning a week before chem- } \\
\text { otherapy and continued until } \\
\text { disease progression) }\end{array}$ & $\begin{array}{l}4 \text { PRs to CT + HV and } 1 \text { in CT + } \\
\text { PLA. } 29 \% \text { and } 32 \% \text { stable dis- } \\
\text { ease, respectively. Median PFS: } 6 \\
\text { months for CT + PLA, } 10 \text { months } \\
\text { for CT + HV. }\end{array}$ & $\begin{array}{l}\text { Low incidence of grades } 3 \text { and } 4 \text { toxicity } \\
\text { in both arms. G } 2 / 3 \text { thrombocytopenia, } \\
\text { edema, drowsiness and tremor were } \\
\text { statistically higher in CT+HV arm. }\end{array}$ \\
\hline Zhou, 2013111 & 40 & II, R & Proteasome & $\begin{array}{l}\text { rAd-p53 combined with chemo- } \\
\text { therapy (PCG arm) vs chemo- } \\
\text { therapy alone (CG arm) }\end{array}$ & $\begin{array}{l}\text { ORR } 95 \% \text { in PCG arm versus } \\
75 \% \text { for the CG arm. 1-year OS: } \\
90 \% \text { and } 65 \% \text {, respectively. }\end{array}$ & $\begin{array}{l}\text { Fever was found in } 90 \% \text { of PCG patients } \\
\text { (mild to medium grade). No serious } \\
\text { adverse events relative to rAd-p53 were } \\
\text { observed. }\end{array}$ \\
\hline
\end{tabular}

ORR: Overall response rate; OS: Overall survival; TTP: Time to progression; PFS: Progression free survival; iv: intravenously; R: randomized; GI: gastrointestinal.

Table 2. Ongoing clinical trials of targeted agents in cervical cancer

\begin{tabular}{|c|c|c|c|c|c|}
\hline Study & $\begin{array}{l}\text { Estimated } \\
\text { Enrollment }\end{array}$ & Phase & Regimen & Target & Primary endopoint \\
\hline DDPDRO-002 & 30 & I/II & Sorafenib with radiation and cisplatin & Multikinase & $\begin{array}{l}\text { Determine the biologic activity of sorafenib in cervix } \\
\text { cancer }\end{array}$ \\
\hline NCT01229930 & 130 & II & $\begin{array}{l}\text { Carboplatin and paclitaxel with or with- } \\
\text { out cediranib maleate }\end{array}$ & VEGF & Overall progression-free survival \\
\hline NCT01065662 & 50 & $\mathrm{I} / \mathrm{IB}$ & Temsirolimus with cediranib & VEGF & $\begin{array}{l}\text { Maximum tolerated dose of cediranib with temsiroli- } \\
\text { mus }\end{array}$ \\
\hline NCT01267253 & 51 & II & Brivanib alaninate monotherapy & VEGF and FGFR & $\begin{array}{l}\text { Progression-free survival for at least } 6 \text { months, objective } \\
\text { tumor response, adverse events as assessed by NCI } \\
\text { CTCAE v } 4.0\end{array}$ \\
\hline NCT00957411 & 76 & II & $\begin{array}{l}\text { Cisplatin and pelvic radiotherapy with or } \\
\text { without cetuximab }\end{array}$ & EGFR & Recurrence-free survival at 2 years \\
\hline NCT01158248 & 50 & II & $\begin{array}{l}\text { Panitunumab with cisplatin and radio- } \\
\text { therapy }\end{array}$ & EGFR & $\begin{array}{l}\text { Progression-free survival at } 4 \text { months and rate of skin } \\
\text { and/or gastrointestinal toxicity CTCAE grade } 4 \text { at } 4\end{array}$ \\
\hline
\end{tabular}




\begin{tabular}{|c|c|c|c|c|c|}
\hline & & & & & months \\
\hline NTC0188347 & 42 & $\mathrm{I} / \mathrm{II}$ & Mapatumumab with chemoradiation & TRAIL-R1 & Safety, tolerability and efficacy \\
\hline NCT01281852 & 66 & $\mathrm{I} / \mathrm{II}$ & $\begin{array}{l}\text { Veliparib given with paclitaxel and cis- } \\
\text { platin }\end{array}$ & PARP & Toxicities and objective tumor response \\
\hline NCT01266447 & 60 & II & $\begin{array}{l}\text { Veliparib with topotecan and filgrastim or } \\
\text { pegfilgrastim }\end{array}$ & PARP & $\begin{array}{l}\text { Objective response, overall survival time, progres- } \\
\text { sion-free interval }\end{array}$ \\
\hline NCT01237067 & 72 & I & Olaparib with carboplatin & PARP & $\begin{array}{l}\text { Pharmacokinetics and pharmacodynamic effects of the } \\
\text { sequence of administration of olaparib and carboplatin } \\
\text { and the schedule-associated safety of the combination }\end{array}$ \\
\hline NCT01076400 & 7 & $\mathrm{I} / \mathrm{II}$ & MK-1775 with cisplatin and topotecan & WEE1 & Objective response rate and maximum tolerated dose \\
\hline NCT01711515 & 18 & I & $\begin{array}{l}\text { Ipilimumab after adjuvant chemoradia- } \\
\text { tion }\end{array}$ & CTLA-4 & $\begin{array}{l}\text { Maximum tolerated dose (MTD) and dose-limiting } \\
\text { toxicities (DLT) of adjuvant ipilimumab }\end{array}$ \\
\hline
\end{tabular}

\section{I Antibodies}

Bevacizumab, a humanized monoclonal antibody directed against VEGF-A, was the first clinically available antiangiogenetic agent successfully tested in many solid tumors [20], including cervical cancer. In 2006, a small retrospective trial suggested activity of bevacizumab in combination with 5-fluorouracil in pretreated cervical cancer patients [21] and, since then, several clinical trials have been carried out. The multicenter GOG 227C phase II trial, evaluating bevacizumab as single agent in recurrent squamous cervical cancer patients, showed encouraging results in response rates $(11 \%)$, percentage of patients without progression at 6 months (24\%), median PFS (3.4 months) and median overall survival (OS) (7.2 months), even if toxicities related to bevacizumab were reported [22]. Since results observed were not inferior to other reports with single chemotherapy agents in this setting, this justifies a phase III trial in combination with chemotherapy in advanced and recurrent cervical cancer, evaluating four chemotherapy regimens with or without bevacizumab, recruiting a total of 450 patients. Preliminary results of this trial showed an advantage in OS, with 17 months in bevacizumab arms versus 13 months in the chemotherapy arms [23]. Another trial investigated the combination of bevacizumab with radiotherapy and cisplatin in untreated locally advanced cervical carcinoma; 60 patients with stage IB-IIIB were enrolled, and preliminary results showed the feasibility of the regimen [24]. The combination of bevacizumab with topotecan and cisplatin as first-line treatment for recurrent or persistent cervical cancer was evaluated in 27 patients, with objective responses in $33.3 \%$ of the patients, a median PFS of 7.1 months and a median OS of 13.2 months, but relevant toxicity was observed, most patients requiring unanticipated hospital admission for supportive care or managing side effects [25].

\subsection{Receptor tyrosine kinase (RTK) inhibitors}

Novel VEGF RTK inhibitors, such as sunitinib, sorafenib, imatinib, pazopanib, cediranib, are being tested in phase I-II clinical trials in cervical cancer. A phase II trial of sunitinib in locally advanced or metastatic pretreated cervical cancer has recently reported no objective responses and $84 \%$ of stable disease in 19 enrolled patients, with high rate of fistula development [26]. Sorafenib is being tested in DDPDRO-002 trial in T1b-3b N0/1 cervical carcinoma, in combination with cisplatin and radiation. Imatinib, an inhibitor of ABL tyrosine that inhibits PDGFR and c-kit, has been tested as a single agent in recurrent cervical cancer expressing PDGFR- $a$, but no responses were observed, even though $>10 \%$ of tumor cells express PDGFR- $\alpha$ in all patients enrolled [27]. A phase II study of pazopanib or lapatinib monotherapy compared with their combination was carried out in 228 stage IV pretreated cervical cancer patients. The combination arm was discontinued because the futility boundary was crossed for combination therapy versus lapatinib monotherapy as well as toxicity, while pazopanib as a single agent improved response rate and PFS over lapatinib, with a favourable toxicity profile [28,29]. Another VEGF receptor inhibitor, cediranib, is being tested in combination with carboplatin, paclitaxel or temsirolimus in phase II (NCT01229930) and phase I trials (NCT01065662) in advanced cervical cancer. Other compounds targeting angiogenesis, such as brivanib, an oral dual inhibitor of VEGF and the fibroblast growth factor (FGF) receptors, are currently under clinical evaluation (NCT01267253).

\subsection{Angiopoietins}

Angiopoietins (ANGPTs) are ligands of endothelial cell receptor TIE2, where both ANGPT1 and ANGPT2 play a role in angiogenesis in maintaining the integrity of existing vessels [30]. Based on preclinical evidence, two ANGPT traps are in early clinical development in cervical cancer, AMG386 and PF-4856884.

Overall, preliminary results on antiangiogenetic agents in cervical cancer are encouraging, and many other clinical studies are ongoing, but larger phase III trials are needed to better define the role of agents targeting angiogenesis in this disease. 


\section{EPIDERMAL GROWTH FACTOR (EGF) RECEPTOR FAMILY INHIBITORS}

The EGF family comprises four different RTKs: EGFR (HER1), ErbB-2 (HER2), ErbB3 (HER3), ErbB4 (HER4). They all possess an extracellular ligand-binding domain, a transmembrane domain, and a cytoplasmic tyrosine kinase-containing domain. After endogenous ligand-binding to the extracellular domain, EGFR forms homo or heterodimers and activates the intrinsic tyrosine kinase-containing domain, and consequently a complex network of signal transduction pathways promoting proliferation, invasion and angiogenesis is activated [31]. In squamous cervical cancer EGFR is overexpressed in up to $85 \%$ of cases, usually correlating with higher stages and poor prognosis [32,33]. The HPV-16 E6 and E7 proteins stimulate EGFR expression on epithelial cells, and E5 protein increases recycling of the EGFR to cell surface and alters EGF endocytic trafficking [34]. Disruption of EGFR gene inhibits development of papilloma and carcinoma from immortalized epithelial cells in mice, thus confirming that the EGFR activation pathway is crucial for progression to cervical cancer. The expression of all four members of EGFR/HER family is being evaluated in bioptical samples of various stages of progression from normal to invasive cervical cancer in an ongoing study from our group. The preliminary results showed low or no expression of HER receptors in most normal tissues/CIN1, whereas a high expression of EGFR, combined with moderate/weak expression of the other three members of HER family have been observed in CIN2-CIN3. An increased expression of EGFR, HER2 and HER4 was reported in invasive cervical cancer, while no HER3 expression was observed, suggesting HER3 overexpression being linked to an early gene of high risk HPV [35].

EGFR modulates tumor chemosensitivity and radiosensitivity [36], while radiotherapy seems to increase its expression in tumor cells [37]. Moreover, the co-expression of EGFR and HER2 receptor in locally advanced cervical cancer patients treated with concurrent chemoradiation had a negative prognostic significance in terms of PFS and disease free survival (DFS) [38]. The EGFR expression is related to shorter DFS and a higher rate of pelvic recurrence in patients with cervical cancer treated with chemoradiation, thus confirming an increase in radio-resistance $[39,40]$. The relation between EGFR and cisplatin or radiotherapy response might be explained by the fact that EGFR is involved in DNA double-strand break repair, and radiation-induced EGFR activation through the PI3k/Akt pathway results in DNA break repair [41,42]. Moreover, radiation may activate EGFR even in the absence of ligand binding, causing inhibi- tion of apoptosis and promotion of cell proliferation [43]. There is less evidence for the prognostic significance of the other receptors of the EGFR family, because HER2 is rarely expressed, and HER3 did not show any correlation with survival, while HER4 seems to be associated with good DFS in cervical cancer patients after radiation [11].

EGFR/HER family inhibitors, such as gefitinib, erlotinib, cetuximab, lapatinib, trastuzumab, panitumumab, are being evaluated in cervical cancer.

Gefitinib, an oral EGFR tyrosine kinase (TK) inhibitor, was investigated as a single agent in a phase II trial in patients with recurrent cervical cancer, with no response rate and disease stabilization of almost 3 months in $21 \%$ of patients treated as second-third line [44]. Erlotinib, a small molecule that reversibly competes with ATP for binding the tyrosine kinase domain of EGFR, was investigated against HPV-infected cells. It was observed that it prevented immortalization of human cervical epithelial cells by the complete HPV-16 genome or the E6/E7 genes; this translates into apoptosis in cells expressing E6/E7, and senescence stimulation in surviving cells [34]. Since viral oncoproteins play a crucial role in early events in carcinogenesis process, thus, preventing cells immortalization through blocking EGFR function by erlotinib or other EGFR inhibitors may represent a novel strategy for chemoprevention or treatment in early stages of cervical carcinogenesis. Erlotinib showed synergistic effects with cisplatin or doxorubicin in preclinical studies $[45,46]$, and EGFR-blocking sensitizes cells to radiation [37]. The activity of single agent erlotinib on invasive squamous cervical cancer patients was tested by GOG 227D trial, with no objective responses [47]. Cetuximab is a chimeric immunoglobulin G2 monoclonal antibody (MoAb) derived from the murine MoAb 225. Preclinical studies in cervical cancer showed sensitivity to cetuximab-mediated cellular cytotoxicity and tumor growth inhibition [48]. A previous small retrospective analysis of cetuximab as a single agent in cervical cancer patients reported disappointing results [49]. The preliminary results of a GOG completed trial are negative: the addition of cetuximab to cisplatin in persistent or recurrent cervical cancer patients showed to increase toxicities only [50]. A phase II trial evaluating cetuximab plus cisplatin and topotecan showed 32\% of objective responses, but considerable toxicity was observed [51]. Moreover, a $14 \%$ of KRAS mutation was described in adenocarcinomas, while it was observed only in $1.4 \%$ of squamous cervical cancers; this suggests a possible role of KRAS mutation in EGFR-targeting agents activity in cervical carcinoma [52]. At present, no advantage in PFS and OS have been reported in other clinical experiences with ce- 
tuximab, alone or in combination with standard chemotherapy $[49,51,53]$. A phase II trial incorporating cetuximab, cisplatin and radiation in women with locally advanced cervical cancer is currently ongoing (NCT00957411). Lapatinib, an oral EGFR-TK inhibitor with anti-HER2 activity, as previously reported in the antiangiogenetic paragraph, was investigated in cervical cancer patients versus pazopanib, another oral TK inhibitor targeting VEGFR, PDGFR, and c-kit, versus the combination of the two agents, and the results indicated superiority of pazopanib over lapatinib $[28,29]$.

HER2 overexpression has been rarely $(<20 \%)$ reported in invasive cervical cancer, and more frequently in adenocarcinoma than in squamous cell carcinoma [54]. Moreover, in contrast with breast carcinoma, the overexpression of HER2 has controversial prognostic significance [19], being associated with both poor survival and favourable results $[55,56]$. Due to the low expression of HER2 in invasive cervical cancer, there is little rationale for testing anti-HER2 treatments such as trastuzumab in patients with cervical carcinoma. Panitumumab, another MoAb targeting EGFR and blocking tumor growth and cells spread [57], is being tested in combination with cisplatin and radiotherapy in stages IB-III KRAS wild-type cervical cancer (NCT01158248).

\section{CYCLOOXYGENASE-2 INHIBITORS}

Cyclooxygenase-2 (COX-2), an enzyme converting arachidonic acid to prostaglandins (PG), is involved in inflammatory processes, and it is frequently expressed in CIN, in cervical cancer and not in normal cervical tissue. Moreover, it is usually associated with apoptosis inhibition and angiogenesis promotion [58]. E6 and E7 oncoproteins contribute to carcinogenesis through enhancing COX-2 transcription by activating EGFR-Ras MAP kinase pathway, while E5 upregulates COX-2 expression through EGFR pathway $[59,60]$. COX-2 pathway plays a role in radiotherapy response, with its inhibition being related to higher responses, through an inhibition of DNA damage repair after radiation, with immunostaining of COX-2 related to poor survival, and the co-expression with EGFR confirming the negative impact on prognosis [61-64].

It has been reported that in celecoxib (a selective Cox-2 inhibitor)-treated cervical cancer patients tumor biopsies showed a decrease in COX-2, ki-67 and CD31, as well as a decrease in microvessel density, with increased prostaglandin E2 (PGE2) expression [65]. In a phase II trial in locally advanced cervical cancer, patients treated with definitive chemoradiation in combination with celecoxib, no advantages in response rates have been observed, and unexpected cardiotoxicity and fistula formation have been reported [66]. Recently, COX-2 expression and survival of patients with locally advanced cervical cancer treated with chemoradiation and celecoxib was analysed, showing a low COX-2 expression in pre-treatment biopsies associated with worse OS [67]. Despite promising evidence of celecoxib radiosensitizer in various tumors, no significant benefits have been reported in cervical cancer, with increase in toxic effects; however, celecoxib has shown some potential as medical treatment for cervical pre-invasive disease [68].

\section{SRC INHIBITORS}

Src kinases are signal transducers activated by different classes of cell-surface receptors, mainly EGFR, insulin growth receptor (IGF-R), hepatocyte growth factor receptor (HGF-R), focal adhesion kinase (FAK), cytokine receptors and others, and most of invasive cervical cancers overexpress EGFR, HGF-R, IGF-R, Src and VEGF $[18,69,70]$. Preclinical studies report that HPV 16 oncoproteins upregulates Src family kinases via post-transcriptional mechanisms. Moreover, E7 enhances the activating phosphorylation of Src kinases expresses in keratinocytes [71], thus, the Src kinase family may be a potential target for the treatment of this cancer.

Src inhibitors have recently been approved in some malignancies [72], and preclinical studies suggest that downregulation of Src TK with Src inhibitors contributes to growth inhibition of cervical cancer cells [73-75]. On the basis of preclinical reports, Src inhibitors, such as dasatinib, may represent promising therapeutic agents for human cervical cancer, even if clinical trials are necessary to verify this hypothesis.

\section{6. mTOR INHIBITORS}

The mammalian target of rapamycin (mTOR) is a serine-threonine kinase that regulates cell growth and cell cycle progression integrating signals from growth factors. Aberrant activation of the mTOR pathway may occur through increased signalling from IGFR, EGFR, activating mutations or amplification of kinase genes, or by loss of function of phosphate and tensin homolog (PTEN) [76]. Evidence suggest an interaction between HPV oncoproteins and mTOR pathway $[77,78]$.

The pathway of mTOR is activated in a wide range of malignancies, including cervical cancer. Preclinical studies evidenced PI3K overexpression in cervical cancer cell lines, and growth inhibition with a PI3K inhibitor [79]. Squamous cervical tumors have shown overexpression of phosphorylated mTOR and its downstream mediators compared to normal cervical epithelium [78]. Chromosomal gain has been 
observed in cervical cancer progression, in the locus of putative PI3KCA, and an increased copy number is reported in up to $70 \%$ of cases $[80,81]$. E6 interacts and degrades tuberous sclerosis complex 2 (TSC2), leading to enhanced mTOR activity [82]. Moreover, overexpression of mTOR in pre-invasive and invasive squamous cell carcinoma results in the phosphorylation and activation of mTOR target 4E-BP1, which in turns leads to translational synthesis of E7 [83]. mTOR inhibition by rapamicin decreases cell lines proliferation and down-regulates mTOR/4EBP1 expression [84]. Recently, it has been reported that in cervical cancer patients treated with chemoradiation, PIK3CA mutations, frequently observed in squamous subtype, are associated with poor PFS and OS in FIGO stages IB/II, while this correlation was not found in more advanced stages [85]. Preliminary results of a phase II trial with temsirolimus, a mTOR inhibitor, in patients with locally advanced or metastatic cervical cancer showed modest activity [86]. The feasibility of combination of weekly temsirolimus and topotecan has been evaluated in advanced gynaecologic malignancies, including cervical cancer [87]. Further clinical trials with temsirolimus, alone or in combination with chemoradiation, are currently ongoing [88].

\section{DEMETHYLATING AGENTS, HISTONE DEACETYLASE INHIBITORS}

DNA methylation is a well-known contributor to regulating gene transcription, mostly through transcriptional silencing, and differences in promoter hypermethylation and subsequent silencing contribute to prognosis and responses to anticancer agents observed in various tumors. In cervical cancer, carcinogenesis is related to aberrant methylation of $\mathrm{CpG}$ island of p16, fragile histidine triad (FHIT) tumor suppressor gene, retinoic acid receptor beta, E-cadherin, death-associated protein kinase, HIC-1 gene, anaphase-promoting complex (APC) and Ras family genes [89]. Preclinical data show how hypermethylation of the CpG island located at the long control region of the HPV genome may regulate the expression of E6 and E7, and reports show downregulation of E6 gene transcription by long control region methylation in cervical cancer cells [90]. Aberrant hypermethylation of the mitotic checkpoint gene CHFR correlates with lack of sensitivity to taxanes in cervical cancer cells [91]. Other reports suggest how aberrant DNA hypermethylation of WRN gene, a gene related to DNA repair mechanisms and replication, increased sensitivity of cervical cancer cells to CPT-11[89]. Demethylating agents, such as decitabine or 5-aza-2' deoxycytidine, may determine re-expression of some tumor suppressor genes and are considered amongst the most innovative therapeutic strategies in cancer treatment, including cervical cancer [92,93].

Histone acetylase (HAT) and histone deacetylase (HDAC) regulates the transcriptional activity of many genes, and inhibition of HDACs can modulate tumor suppressor gene expression and cooperate with other therapeutic modalities. In HPV positive cells, HDAC binds to E7 preventing HDAC binding to E2F promoter, leading to upregulation of E2F and increase proliferation [94]. Tricostatin $A$, a HDAC inhibitor, can compete with E6 for p53 binding, resulting in p53 hyperacetylation and increased apoptosis, and clinical trials in combination with chemoradiation are ongoing $[95,96]$. Vorinostat, another histone deacetylase inhibitor, is under evaluation in respiratory papillomatosis, a disease related to HPV virus other than 16 and 18 [97]. Valproic acid (VPA) is a HDAC inhibitor tested, alone and in combination with retinoids or somatostatin receptor 2 cytotoxic conjugate agents, in preclinical studies of cervical HeLa cells $[98,99]$. Preliminary results of a phase III randomized trial of hydralazine-valproate versus placebo added to cisplatin/topotecan showed advantages in PFS for epigenetic treatment [100].

\section{PROTEASOME INHIBITORS}

Cervical cancer cells have shown an increased requirement for ubiquitin-dependent protein degradation and an elevated metabolic turnover rate, related to HPV E6-targeted degradation of p53 and PDZ domain-containing protein. E6 binds the E3 ubiquitin ligase E6-AP and redirects its activity towards p53 and other tumor suppressor proteins for their ubiquitin-mediated proteasomal degradation [101]. Proteasome inhibitors, by preventing ubiquitin-proteasome protein degradation, can modulate p53 degradation [102]. MG132 increases p53 protein levels and transcriptional activity in cervical cancer cell lines, sensitizes cells to TRAIL-receptor or apoptosis, and radiosensitizes under hypoxia [103]. Bortezomib, a selective proteasome inhibitor, has synergy with cisplatin in cervical cancer cell lines [104] and, combined with radiation, showed feasibility in initial reports [105]. The HIV protease inhibitor and proteasome inhibitor lopinavir $[106,107]$ has been shown to stabilize p53 protein and to induce apoptosis in HPV positive cell lines [108]. A recent preclinical study on cervical carcinoma cell lines confirmed sensitivity to lopinavir, suggesting its hypothetical role in treating pre-neoplastic HPV-related lesions [109]. Moreover, the combination of bortezomib and nelfinavir, a HIV protease inhibitor, showed efficacy in chemoresistant cervical cancer cells [110].

An alternative to proteasome inhibition in inducing p53 stabilization is increasing wild-type p53 production by recombinant adenovirus-p53(rAd-p53). 
To evaluate efficacy and safety of $r A d-p 53$ combined with chemotherapy in locally advanced cervical cancer, a phase II randomized trial is currently evaluating the combination treatment versus chemotherapy only, with preliminary results showing feasibility and higher efficacy in terms of response rate and 1-yr survival in the combination arm [111]. Extrinsic apoptotic pathway can be activated by binding apoptosis-inducing death ligands, such as Fas ligand (FasL) or tumor necrosis factor (TNF)-related apoptosis inducing ligand (TRAIL) to cell surface receptors, with subsequent activation of apoptotic cascade [112]. Proteasome inhibition can enhance recombinant TRAIL-induced apoptosis in HPV positive cervical cells, and MoAbs against TRAIL have shown preclinical activity [113]. A clinical phase I-II trial is ongoing, evaluating mapatumumab with chemoradiation in locally advanced cervical cancer (NTC01088347).

\section{PARP INHIBITORS}

PARP (Poly ADP-ribose) polymerase -1 and 2 is a family of 17 enzymes, where only PARP1 and PARP2 are known to be involved in the double-strand break DNA repair by homologous recombination (HR) system [114]. PARP inhibitors might potentiate the cell-killing ability of cisplatin and heterogeneous results are described in cervical cell lines (HeLa) [115]. A relevant synergy effect is described with other DNA-damaging agents and with ionizing radiation. In cervical cancer cell lines treated with radiation or topotecan, this synergy was confirmed, supporting enhanced radio-chemotherapy toxicity in cancers proficient in DNA double-strand repair when PARP is inhibited by veliparib, an oral PARP inhibitor [116]. Synergy may in part be explained by the PARP inhibitor induction of apoptosis in cervical cancer cells [117]. Moreover, in cervical cancer, the 11 p15 chromosomal region where BRCA and Fanconi anemia complementation group F (FANCF) is mapped, shows frequent loss of heterozygosity, and FANCF is commonly inactivated by epigenetic alteration, leading to other genes inactivation, i.e. BRCA1-2, with chromosomal hypersensitivity to DNA-damaging agents [118]. Two clinical phase I-II trials are now ongoing in the USA (NCT 01281852; NCT01266447), evaluating veliparib, in combination with paclitaxel and cisplatin or topotecan, in patients with advanced, persistent or recurrent cervical cancer. Moreover, a phase I ongoing trial is evaluating olaparib in combination with carboplatin/paclitaxel in advanced cervical cancer (NCT01237067).

\section{WEE1 AND CELL CYCLE CONTROL}

Entry into mitosis is regulated by the cyclin-dependent kinase-1 (CDK1)/cyclin B complex, whose activity is balanced by inactivating phosphorylation by the protein kinase WEE1 and myelin transcription factor 1 (MYT1), and by activating dephosphorylation by CDC25. WEE1 gene is overexpressed in cervical cancer cells, and may be silenced by siRNA, and this, in combination with adriamycin, results in apoptosis. Moreover, given that p53 is a key regulator in the $\mathrm{G}(1)$ checkpoint, p53-deficient tumors, such as cervical cancer, rely only on the check G(2) checkpoint after DNA damage, and WEE1 inhibition selectively sensitized these tumors to DNA damaging agents. The combination of MK1775, a WEE1 inhibitor, with carboplatin in cervical HeLa-luc xenografts, resulted in tumor growth inhibition [119]. Recently, a number of small molecules WEE1 inhibitors were evaluated in early clinical trials, as single agents, or in combination with chemotherapy, including $M K-1775$, which is being tested in combination with cisplatin and topotecan in advanced cervical cancer (NCT01076400).

\section{ANTIOXIDANTS}

Oxidative stress represents an interesting promoting factor in HPV related carcinogenesis, and it is known to perturb cellular redox status leading to gene expression response alteration through activation of redox sensitive transcription factors, thus affecting cell growth and death. During cervical carcinogenesis an increase in oxidative DNA damage has been reported, as shown by the progressive increase in levels of 8-OHdG from normal tissue to CIN and to invasive cervical cancer [120]. Among antioxidant agents, polyphenols demonstrated to inhibit the proliferation of HPV-immortalized and HPV-positive cancer cells, and have been found to be promising drugs for cervical cancer. They display many other biological functions, including induction of apoptosis, growth arrest, DNA synthesis inhibition, and modulation of other signal transduction pathways. Polyphenol activity as cisplatin chemosensitivity enhancement is also described in cervical cancer cells through apoptosis induction [121]. Ongoing clinical trials show encouraging preliminary data [122].

\section{NOTCH SIGNALLING}

The Notch gene family encodes heterodimeric type I transmembrane receptors, which is involved in cell-cell communication, playing a role in proliferation, differentiation, and apoptosis. Notch receptors and ligands are aberrantly expressed in cancers, including cervical cancer, acting as either a tumor suppressor or as an oncogene [123]. Notch signalling pathway is a key determinant in keratinocyte differentiation and growth cycle arrest, and has a tumor suppressor function in the skin, so there is a link with 
the HPV life cycle. In particular, cutaneous beta-HPV E6 protein inhibits Notch signalling [124]. Notch signalling may have different role during cervical cancer cancerogenesis, Notch 1 being upregulated in the early stages and reduced in the late stages of cervical cancer. It has recently been reported that Notch 1-induced tumor suppression may be related to somatostatin (SST) signalling. It also reported an activation of somatostatin receptor (SSTR), enhancing SSTR-mediated target therapy. VPA, previously described as a hystone deacetylase inhibitor, suppresses cell growth and upregulates the expression of Notch 1 and SSTR2, acting also as an activator of Notch and SST signalling, consequently having an additive effect in suppression combining VPA and the SSTR2-targeting cytotoxic conjugate in cervical cancer HeLa cells [123], thus suggesting other relevant molecular targets in cervical cancerogenesis.

\section{MICRO RNAs (miRNA) and RNA INTERFERING (siRNAs)}

MicroRNAs (miRNA) are a new family of small endogenous RNAs with diverse sequences, implicated in post-transcriptional regulatory mechanisms for silencing sequence-specific genes. miRNAs act on mRNA by arresting the translation or by inducing the cleavage of target mRNA [125], and regulating individual components of multiple oncogenic pathways. Downregulation of miRNA may be associated with worse prognosis in cervical cancer, and may be considered a potential therapeutic target and prognostic marker. Short interfering RNA (siRNAs) are non-coding RNAs 21-25 nucleotides in length that mimic endogenous miRNA which can effectively inhibit the translation of target mRNA by binding to their 3'-UTR. siRNA, antisense oligodeoxynucleotides or ribozymes specific for E6 and E7, have shown preclinical activity in cervical cancer cells or animal models through transcriptional genes silencing, restoring normal $\mathrm{p} 53$ and $\mathrm{Rb}$ functions leading to cells apoptosis [8,126]. In preclinical studies therapeutic siRNAs targeting E6/E7, alone and in combination with chemoradiation or chemotherapy, significantly inhibit tumor growth [127,130]. A better selection of cloning vectors, molecular transport vehicles, dosing and schedule of siRNAs are still under evaluation, as well the optimal combination with chemotherapy, radiation or immunotherapy in cervical cancer.

\section{ANTIVIRAL AGENTS}

In the early phases of viral cancerogenesis several different antiviral approaches have been considered, mainly acting through the inhibition of the oncoprotein E6 and E7 directly or by interfering with their related functions [131-134]. Lopinavir, an antivi- ral agent employed in HIV disease, interacts with p53, and has shown activity in cervical cancer cell lines [109], suggesting possible clinical use. Another approach was based on a close and complex interaction between E1 viral protein and the cellular protein p80, which leads to HPV DNA replication [135], thus suggesting a hypothetical therapeutic role of peptides inhibiting E1-p80 binding. Indeed, an E1-derived N40-inhibitory peptide is known to be able to lock HPV DNA replication in vitro. Other small molecular compounds have been found by inhibiting E1/E2, and some of them act at low molecular concentration, suggesting a possible clinical utilization in the near future. Finally, cydofovir, an acyclic nucleoside phosphonate with broad spectrum anti-viral activity, has been topically employed in CIN2/CIN3 lesions in a randomized trial, with favourable results [136].

\section{MISCELLANEOUS}

A number of other molecular pathways are involved in cervical cancer cancerogenesis, where preclinical studies suggest they may be potential therapeutic targets. Among them, aberrant activation of Wingless-type (Wnt)/beta-catenin signalling, increased expression of NFBD1/MDC1 protein, increased expression of Hedgehog signalling, or HIF-1A signalling $[118,137]$, and preclinical studies are currently ongoing. Preliminary results of immunological treatments and of therapeutic vaccines are promising, but they are still in the early phases of development focusing mainly on pre-neoplastic cervical lesions.

\section{CONCLUSIONS}

There is an urgent need for more effective treatments in recurrent/advanced cervical cancer and many molecularly targeted agents have recently been evaluated in clinical trials. At present, the main focus of interest is tumor angiogenesis, with many antiangiogenetic agents being tested in randomized trials, and bevacizumab achieving promising results [23]. Beside angiogenesis, other molecular pathways have been explored, and many other agents targeting various biological pathways are still under evaluation, most of them still in the early phases of development. Moereover, there is also a clinical need for preneoplastic lesions. The biological and clinical behaviour underlying CIN2-CIN3 is still uncertain, since only an unpredictable part of them will progress to invasive cancer when untreated. Thus, a therapeutic strategy capable of interrupting the progression to malignancy for this wide subset of patients remains a significant challenge. Innovative technologies, such as whole genome sequencing, will further provide the individual with a tumor genetic profile, facilitating the selection of a more personalized therapeutic program. 
However, it is absolutely necessary to improve our understanding on the key points involved in the malignant transformation and progression of cervical cancer. Translational studies are currently focusing on these issues, trying to better elucidate the mechanisms involved in this complex cancerogenesis and aiming to identify valid prognostic and predictive biomarkers in selecting more personalized treatments.

\section{Abbreviations}

VEGF: vascular endothelial growth factor; EGFR: epidermal growth factor receptor; HPV: Human papillomavirus; CIN: cervical intraepithelial neoplasia; PFS: progression free survival; HIF-1a: hypoxia-inducibile factor-1a; PI3K: phosphatidylinositol 3-kinase; ERK1/2: MEK-extracellular signal-regulated kinase 1/2; PG: prostaglandin; RTK: receptor tyrosine kinase; FGF: fibroblast growth factor; DFS: disease free survival; TK: tyrosine kinase; MoAb: monoclonal antibody; COX-2: Cyclooxygenase-2; OS: overall survival; IGF-R: insulin growth receptor; HGF-R: hepatocyte growth factor receptor; FAK: focal adhesion kinase; mTOR: mammalian target of rapamycin; PTEN: phosphate and tensin homolog; TSC2: tuberous sclerosis complex 2; HAT: Histone acetylase; HDAC: histone deacetylase; rAd-p53: recombinant adenovirus-p53; FasL: Fas ligand; TNF: tumor necrosis factor; TRAIL: TNF-related apoptosis inducing ligand; PARP: Poly ADP-ribose polymerase; HeLa: cervical cell lines; HR: homologous recombination; FANCF: Fanconi anemia complementation group F; CDK1: cyclin-dependent kinase-1; MYT1: myelin transcription factor 1; SST: somatostatin; SSTR: somatostatin receptor; miRNA: microRNAs; siRNAs: short interfering RNA.

\section{Acknowledgement}

We thank Tania Merlino and Anna Maria Edlisca for technical assistance.

\section{Authors' contributions}

The outline was conceived by PV. All authors contributed to initial drafts, edited version, and the final version. All authors read and approved the final manuscript.

\section{Competing Interests}

The authors have declared that no competing interest exists.

\section{References}

1. Jemal A, Bray F, Center MM, et al. Global cancer statistics. CA Cancer J Clin. 2011; 61: 69-90.

2. Mountzios G, Soultati A, Pectasides D, et al. Developments in the systemic treatment of metastatic cervical cancer. Cancer Treat Rev. 2013; 39: 430-43.

3. Kim MK, Kim HS, Kim SH, et al. Human papillomavirus type 16 E5 oncoprotein as a new target for cervical cancer treatment. Biochem Pharmacol. 2010; 80: $1930-5$.
4. Werness BA, Levine AJ, Howley PM. Association of human papillomavirus types 16 and 18 E6 proteins with p53. Science. 1990; 248: 76-9.

5. Dyson N, Howley PM, Münger K, et al. The human papilloma virus-16 E7 oncoprotein is able to bind to the retinoblastoma gene product. Science. 1989; 243: 934-7.

6. Scheffner M, Huibregtse JM, Vierstra RD, et al. The HPV-16 E6 and E6-AP complex functions as a ubiquitin-protein ligase in the ubiquitination of p53. Cell. 1993; 75: 495-505.

7. Chen JJ. Genomic Instability Induced By Human Papillomavirus Oncogenes. N Am J Med Sci (Boston). 2010; 3: 43-7.

8. Tan S, de Vries EG, van der Zee AG, et al. Anticancer drugs aimed at E6 and E7 activity in HPV-positive cervical cancer. Curr Cancer Drug Targets. 2012; 12: $170-84$.

9. Cheng WF, Chen $\mathrm{CA}$, Lee $\mathrm{CN}$, et al. Vascular endothelial growth factor and prognosis of cervical carcinoma. Obstet Gynecol. 2000; 96: 721-6.

10. Hashimoto I, Kodama J, Seki N, et al. Vascular endothelial growth factor-C expression and its relationship to pelvic lymph node status in invasive cervical cancer. Br J Cancer. 2001; 85: 93-7.

11. Lee JS, Kim HS, Jung JJ, et al. Expression of vascular endothelial growth factor in adenocarcinomas of the uterine cervix and its relation to angiogenesis and p53 and c-erbB-2 protein expression. Gynecol Oncol. 2002; 85: 469-75.

12. Gaffney DK, Haslam D, Tsodikov A, et al. Epidermal growth factor receptor (EGFR) and vascular endothelial growth factor (VEGF) negatively affect overall survival in carcinoma of the cervix treated with radiotherapy. Int J Radiat Oncol Biol Phys. 2003; 56: 922-8.

13. Mitsuhashi A, Suzuka K, Yamazawa K, et al. Serum vascular endothelial growth factor (VEGF) and VEGF-C levels as tumor markers in patients with cervical carcinoma. Cancer. 2005; 103: 724-30.

14. Willmott LJ, Monk BJ. Cervical cancer therapy: current, future and anti-angiogensis targeted treatment. Expert Rev Anticancer Ther. 2009; 9: 895-903.

15. Nakamura M, Bodily JM, Beglin M, et al. Hypoxia-specific stabilization of HIF-1alpha by human papillomaviruses. Virology. 2009; 387: 442-8.

16. Kim SH, Juhnn YS, Kang S, et al. Human papillomavirus 16 E5 up-regulates the expression of vascular endothelial growth factor through the activation of epidermal growth factor receptor, MEK/ ERK1,2 and PI3K/Akt. Cell Mol Life Sci. 2006; 63: 930-8

17. Oh JM, Kim SH, Lee YI, et al. Human papillomavirus E5 protein induces expression of the EP4 subtype of prostaglandin E2 receptor in cyclic AMP response element-dependent pathways in cervical cancer cells. Carcinogenesis. 2009; 30: 141-9.

18. del Campo JM, Prat A, Gil-Moreno A, et al. Update on novel therapeutic agents for cervical cancer. Gynecol Oncol. 2008; 110 (3 Suppl 2): S72-6.

19. Mathur RS, Mathur SP. Vascular endothelial growth factor (VEGF) up-regulates epidermal growth factor receptor (EGF-R) in cervical cancer in vitro: this action is mediated through HPV-E6 in HPV-positive cancers. Gynecol Oncol. 2005; 97: 206-13.

20. Shih T, Lindley C. Bevacizumab: an angiogenesis inhibitor for the treatment of solid malignancies. Clin Ther. 2006; 28: 1779-802.

21. Wright JD, Viviano D, Powell MA, et al. Bevacizumab combination therapy in heavily pretreated, recurrent cervical cancer. Gynecol Oncol. 2006; 103: 489-93.

22. Monk BJ, Sill MW, Burger RA, et al. Phase II trial of bevacizumab in the treatment of persistent or recurrent squamous cell carcinoma of the cervix: a gynecologic oncology group study. J Clin Oncol. 2009; 27: 1069-74.

23. Tewari KS, Sill M, Long HJ, et al. Incorporation of bevacizumab in the treatment of recurrent and metastatic cervical cancer: A phase III randomized trial of the Gynecologic Oncology Group. J Clin Oncol. 2013; 31(suppl): abstr3.

24. Schefter TE, Winter K, Kwon JS, et al. A phase II study of bevacizumab in combination with definitive radiotherapy and cisplatin chemotherapy in untreated patients with locally advanced cervical carcinoma: preliminary results of RTOG 0417. Int J Radiat Oncol Biol Phys. 2012; 83: 1179-84.

25. Zighelboim I, Wright JD, Gao F, et al. Multicenter phase II trial of topotecan, cisplatin and bevacizumab for recurrent or persistent cervical cancer. Gynecol Oncol. 2013; 130: 64-8.

26. Mackay HJ, Tinker A, Winquist E, et al. A phase II study of sunitinib in patients with locally advanced or metastatic cervical carcinoma: NCIC CTG Trial IND.184. Gynecol Oncol. 2010; 116: 163-7.

27. Candelaria M, Arias-Bonfill D, Chávez-Blanco A, et al. Lack in efficacy for imatinib mesylate as second-line treatment of recurrent or metastatic cervical cancer expressing platelet-derived growth factor receptor alpha. Int J Gynecol Cancer. 2009; 19: 1632-7.

28. Monk BJ, Mas Lopez L, Zarba JJ, et al. Phase II, open-label study of pazopanib or lapatinib monotherapy compared with pazopanib plus lapatinib combination therapy in patients with advanced and recurrent cervical cancer. J Clin Oncol. 2010; 28: 3562-9.

29. Monk BJ, Pandite LN. Survival data from a phase II, open-label study of pazopanib or lapatinib monotherapy in patients with advanced and recurrent cervical cancer. J Clin Oncol. 2011; 29:4845.

30. Nasarre P, Thomas M, Kruse K, et al. Host-derived angiopoietin-2 affects early stages of tumor development and vessel maturation but is dispensable for later stages of tumor growth. Cancer Res. 2009; 69: 1324-33.

31. Hynes NE, Lane HA. ERBB receptors and cancer: the complexity of targeted inhibitors. Nat Rev Cancer. 2005; 5: 341-54.

32. Kersemaekers AM, Fleuren GJ, Kenter GG, et al. Oncogene alterations in carcinomas of the uterine cervix: overexpression of the epidermal growth 
factor receptor is associated with poor prognosis. Clin Cancer Res. 1999; 5: 577-86.

33. Kim JW, Kim YT, Kim DK, et al. Expression of epidermal growth factor receptor in carcinoma of the cervix. Gynecol Oncol. 1996; 60: 283-7.

34. Woodworth CD, Diefendorf LP, Jette DF, et al. Inhibition of the epidermal growth factor receptor by erlotinib prevents immortalization of human cervical cells by Human Papillomavirus type 16. Virology. 2011; 421: 19-27.

35. Mariani L, Vici P, Venuti A, et al. HER family expression in preneoplastic low and high-grade cervical lesions. Int J Gynaecol Obstet 2012; 119 (suppl 3):abstrM406.

36. Pérez-Regadera J, Sánchez-Muñoz A, De-la-Cruz J, et al. Cisplatin-based radiochemotherapy improves the negative prognosis of c-erbB-2 overexpressing advanced cervical cancer. Int J Gynecol Cancer. 2010; 20: 164-72.

37. Liang K, Ang KK, Milas L, et al. The epidermal growth factor receptor mediates radioresistance. Int J Radiat Oncol Biol Phys. 2003; 57: 246-54.

38. Pérez-Regadera J, Sánchez-Muñoz A, De-la-Cruz J, et al. Negative prognostic impact of the coexpression of epidermal growth factor receptor and c-erbB-2 in locally advanced cervical cancer. Oncology. 2009; 76: 133-41.

39. Noordhuis MG, Eijsink JJ, Ten Hoor KA, et al. Expression of epidermal growth factor receptor (EGFR) and activated EGFR predict poor response to (chemo)radiation and survival in cervical cancer. Clin Cancer Res. 2009; 15: 7389-97.

40. Pérez-Regadera J, Sánchez-Muñoz A, De-la-Cruz J, et al. Impact of epidermal growth factor receptor expression on disease-free survival and rate of pelvic relapse in patients with advanced cancer of the cervix treated with chemoradiotherapy. Am J Clin Oncol. 2011; 34: 395-400.

41. Rodemann HP, Dittmann K, Toulany M. Radiation-induced EGFR-signaling and control of DNA-damage repair. Int J Radiat Biol. 2007; 83: 781-91.

42. Toulany M, Kasten-Pisula U, Brammer I, et al. Blockage of epidermal growth factor receptor-phosphatidylinositol 3-kinase-AKT signaling increases radiosensitivity of K-RAS mutated human tumor cells in vitro by affecting DNA repair. Clin Cancer Res. 2006; 12: 4119-26.

43. Dent P, Yacoub A, Contessa J, et al. Stress and radiation-induced activation of multiple intracellular signaling pathways. Radiat Res. 2003; 159: 283-300.

44. Goncalves A, Fabbro M, Lhommé C, et al. A phase II trial to evaluate gefitinib as second- or third-line treatment in patients with recurring locoregionally advanced or metastatic cervical cancer. Gynecol Oncol. 2008; 108: 42-6.

45. Aboud-Pirak E, Hurwitz E, Pirak ME, et al. Efficacy of antibodies to epidermal growth factor receptor against KB carcinoma in vitro and in nude mice. J Natl Cancer Inst. 1988; 80: 1605-11.

46. Fan $\mathrm{Z}$, Baselga J, Masui $\mathrm{H}$, et al. Antitumor effect of anti-epidermal growth factor receptor monoclonal antibodies plus cis-diamminedichloroplatinum on well established A431 cell xenografts. Cancer Res. 1993; 53: 4637-42.

47. Schilder RJ, Sill MW, Lee YC, et al. A phase II trial of erlotinib in recurrent squamous cell carcinoma of the cervix: a Gynecologic Oncology Group Study. Int J Gynecol Cancer. 2009; 19: 929-33.

48. Bellone S, Frera G, Landolfi G, et al. Overexpression of epidermal growth factor type-1 receptor (EGF-R1) in cervical cancer: implications for Cetuximab-mediated therapy in recurrent/metastatic disease. Gynecol Oncol. 2007; 106: 513-20.

49. Hertlein L, Lenhard M, Kirschenhofer A, et al. Cetuximab monotherapy in advanced cervical cancer: a retrospective study with five patients. Arch Gynecol Obstet. 2011; 283: 109-13.

50. Farley J, Sill MW, Birrer M, et al. Phase II study of cisplatin plus cetuximab in advanced, recurrent, and previously treated cancers of the cervix and evaluation of epidermal growth factor receptor immunohistochemical expression: a Gynecologic Oncology Group study. Gynecol Oncol. 2011; 121: 303-8.

51. Kurtz JE, Hardy-Bessard AC, Deslandres M, et al. Cetuximab, topotecan and cisplatin for the treatment of advanced cervical cancer: A phase II GINECO trial. Gynecol Oncol. 2009; 113: 16-20.

52. Kang S, Kim HS, Seo SS, et al. Inverse correlation between RASSF1A hypermethylation, KRAS and BRAF mutations in cervical adenocarcinoma. Gynecol Oncol. 2007; 105: 662-6.

53. Santin AD, Sill MW, McMeekin DS, et al. Phase II trial of cetuximab in the treatment of persistent or recurrent squamous or non-squamous cell carcinoma of the cervix: a Gynecologic Oncology Group study. Gynecol Oncol. 2011; 122: $495-500$

54. Fadare O, Zheng W. HER2 protein (p185(HER2)) is only rarely overexpressed in cervical cancer. Int J Gynecol Pathol. 2004; 23: 410-1 (author reply 411-2)

55. Nevin J, Laing D, Kaye P, et al. The significance of Erb-b2 immunostaining in cervical cancer. Gynecol Oncol. 1999; 73: 354-8.

56. Lee CM, Shrieve DC, Zempolich KA, et al. Correlation between human epidermal growth factor receptor family (EGFR, HER2, HER3, HER4), phosphorylated Akt (P-Akt), and clinical outcomes after radiation therapy in carcinoma of the cervix. Gynecol Oncol. 2005; 99: 415-21.

57. Keating GM. Panitumumab: a review of its use in metastatic colorectal cancer. Drugs. 2010; 70: 1059-78.

58. Kulkarni S, Rader JS, Zhang F, et al. Cyclooxygenase-2 is overexpressed in human cervical cancer. Clin Cancer Res. 2001; 7: 429-34.

59. Kim SH, Oh JM, No JH, et al. Involvement of NF-kappaB and AP-1 in COX-2 upregulation by human papillomavirus 16 E5 oncoprotein. Carcinogenesis. 2009; 30: 753-7.

60. Subbaramaiah K, Dannenberg AJ. Cyclooxygenase-2 transcription is regulated by human papillomavirus $16 \mathrm{E} 6$ and E7 oncoproteins: evidence of a corepressor/coactivator exchange. Cancer Res. 2007; 67: 3976-85.
61. Chen $\mathrm{HH}, \mathrm{Su} \mathrm{WC}, \mathrm{Chou} \mathrm{CY}$, et al. Increased expression of nitric oxide synthase and cyclooxygenase- 2 is associated with poor survival in cervical cancer treated with radiotherapy. Int J Radiat Oncol Biol Phys. 2005; 63: 1093-100.

62. Ferrandina G, Ranelletti FO, Legge F, et al. Prognostic role of the ratio between cyclooxygenase-2 in tumor and stroma compartments in cervical cancer. Clin Cancer Res. 2004; 10: 3117-23.

63. Kim GE, Kim $\mathrm{YB}$, Cho $\mathrm{NH}$, et al. Synchronous coexpression of epidermal growth factor receptor and cyclooxygenase- 2 in carcinomas of the uterine cervix: a potential predictor of poor survival. Clin Cancer Res. 2004; 10: 1366-74.

64. Kim YB, Kim GE, Pyo HR, et al. Differential cyclooxygenase-2 expression in squamous cell carcinoma and adenocarcinoma of the uterine cervix. Int J Radiat Oncol Biol Phys. 2004; 60: 822-9.

65. Ferrandina G, Ranelletti FO, Legge F, et al. Celecoxib modulates the expression of cyclooxygenase-2, ki67, apoptosis-related marker, and microvessel density in human cervical cancer: a pilot study. Clin Cancer Res. 2003; 9: 4324-31.

66. Herrera FG, Chan P, Doll C, et al. A prospective phase I-II trial of the cyclooxygenase-2 inhibitor celecoxib in patients with carcinoma of the cervix with biomarker assessment of the tumor microenvironment. Int J Radiat Oncol Biol Phys. 2007; 67: 97-103.

67. Doll CM, Winter K, Gaffney DK, et al. COX-2 expression and survival in patients with locally advanced cervical cancer treated with chemoradiotherapy and celecoxib: a quantitative immunohistochemical analysis of RTOG C0128. Int J Gynecol Cancer. 2013; 23: 176-83.

68. Young JL, Jazaeri AA, Darus CJ, et al. Cyclooxygenase-2 in cervical neoplasia: a review. Gynecol Oncol. 2008; 109: 140-5.

69. Manavi M, Hudelist G, Fink-Retter A, et al. Gene profiling in Pap-cell smears of high-risk human papillomavirus-positive squamous cervical carcinoma. Gynecol Oncol. 2007; 105: 418-26.

70. Hirano S, Ito N, Takahashi S, et al. Clinical implications of insulin-like growth factors through the presence of their binding proteins and receptors expressed in gynecological cancers. Eur J Gynaecol Oncol. 2004; 25: 187-91.

71. Szalmás A, Gyöngyösi E, Ferenczi A, et al. Activation of Src, Fyn and Yes non-receptor tyrosine kinases in keratinocytes expressing human papillomavirus (HPV) type 16 E7 oncoprotein. Virol J. 2013; 10:79.

72. Al Moustafa AE, Yasmeen A, Alachkar A. Src inhibitors are promising therapy molecules for human cervical carcinomas. Med Hypotheses. 2011; 77: 812-4.

73. Kong L, Deng Z, Shen H, et al. Src family kinase inhibitor PP2 efficiently inhibits cervical cancer cell proliferation through down-regulating phospho-Src-Y416 and phospho-EGFR-Y1173. Mol Cell Biochem. 2011; 348: 11-9.

74. Kong L, Deng Z, Zhao Y, et al. Down-regulation of phospho-non-receptor Src tyrosine kinases contributes to growth inhibition of cervical cancer cells. Med Oncol. 2011; 28: 1495-506.

75. Yasmeen A, Alachkar A, Dekhil H, et al. Locking Src/Abl Tyrosine Kinase Activities Regulate Cell Differentiation and Invasion of Human Cervical Cancer Cells Expressing E6/E7 Oncoproteins of High-Risk HPV. J Oncol. 2010. Article ID 530130

76. Diaz-Padilla I, Duran I, Clarke BA, et al. Biologic rationale and clinical activity of mTOR inhibitors in gynecological cancer. Cancer Treat Rev. 2012; 38: 767-75.

77. Contreras-Paredes A, De la Cruz-Hernández E, Martínez-Ramírez I, et al. E6 variants of human papillomavirus 18 differentially modulate the protein kinase B/phosphatidylinositol 3-kinase (Akt/PI3K) signaling pathway. Virology. 2009; 383: 78-85.

78. Feng W, Duan X, Liu J, et al. Morphoproteomic evidence of constitutively activated and overexpressed mTOR pathway in cervical squamous carcinoma and high grade squamous intraepithelial lesions. Int J Clin Exp Pathol. 2009; 2: 249-60.

79. Zhang XY, Zhang HY, Zhang PN, et al. Elevated phosphatidylinositol 3-kinase activation and its clinicopathological significance in cervical cancer. Eur J Obstet Gynecol Reprod Biol. 2008; 139: 237-44.

80. Heselmeyer K, Schröck E, du Manoir S, et al. Gain of chromosome 3q defines the transition from severe dysplasia to invasive carcinoma of the uterine cervix. Proc Natl Acad Sci USA. 1996; 93: 479-84.

81. Bertelsen BI, Steine SJ, Sandvei R, et al. Molecular analysis of the PI3K-AKT pathway in uterine cervical neoplasia: frequent PIK3CA amplification and AKT phosphorylation. Int J Cancer. 2006; 118: 1877-83.

82. $\mathrm{Lu} \mathrm{Z}, \mathrm{Hu} \mathrm{X}, \mathrm{Li} \mathrm{Y}$, et al. Human papillomavirus $16 \mathrm{E} 6$ oncoprotein interferences with insulin signaling pathway by binding to tuberin. J Biol Chem. 2004; 279: 35664-70.

83. Oh KJ, Kalinina A, Park NH, et al. Deregulation of eIF4E: 4E-BP1 in differentiated human papillomavirus-containing cells leads to high levels of expression of the E7 oncoprotein. J Virol. 2006; 80: 7079-88.

84. Ji J, Zheng PS. Activation of mTOR signaling pathway contributes to survival of cervical cancer cells. Gynecol Oncol. 2010; 117: 103-8.

85. McIntyre JB, Wu JS, Craighead PS, et al. PIK3CA mutational status and overall survival in patients with cervical cancer treated with radical chemoradiotherapy. Gynecol Oncol. 2013; 128: 409-14

86. Tinker AV, Ellard S, Welch S, et al. Phase II study of temsirolimus (CCI-779) in women with recurrent, unresectable, locally advanced or metastatic carcinoma of the cervix. A trial of the NCIC Clinical Trials Group (NCIC CTG IND 199). Gynecol Oncol. 2013. pii: S0090-8258(13)00741-5. 
87. Temkin SM, Yamada SD, Fleming GF. A phase I study of weekly temsirolimus and topotecan in the treatment of advanced and/or recurrent gynecologic malignancies. Gynecol Oncol. 2010; 117: 473-6.

88. Wu J, Chen $\mathrm{C}$, Zhao KN. Phosphatidylinositol 3-kinase signaling as a therapeutic target for cervical cancer. Curr Cancer Drug Targets. 2013; 13: 143-56.

89. Masuda K, Banno K, Yanokura M, et al. Association of epigenetic inactivation of the WRN gene with anticancer drug sensitivity in cervical cancer cells. Oncol Rep. 2012; 28: 1146-52.

90. Ding DC, Chiang MH, Lai HC, et al. Methylation of the long control region of HPV16 is related to the severity of cervical neoplasia. Eur J Obstet Gynecol Reprod Biol. 2009; 147: 215-20.

91. Banno K, Yanokura M, Kawaguchi M, et al. Epigenetic inactivation of the CHFR gene in cervical cancer contributes to sensitivity to taxanes. Int J Oncol. 2007; 31: 713-20.

92. Tanaka T, Bai T, Toujima S, et al. Demethylation restores SN38 sensitivity in cells with acquired resistance to SN38 derived from human cervical squamous cancer cells. Oncol Rep. 2012; 27: 1292-8.

93. Roossink F, de Jong S, Wisman GB, et al. DNA hypermethylation biomarkers to predict response to cisplatin treatment, radiotherapy or chemoradiation: the present state of art. Cell Oncol (Dordr). 2012; 35: 231-41.

94. Brehm A, Nielsen SJ, Miska EA, et al. The E7 oncoprotein associates with Mi2 and histone deacetylase activity to promote cell growth. EMBO J. 1999; 18: 2449-58.

95. de la Cruz-Hernández E, Pérez-Cárdenas E, Contreras-Paredes A, et al. The effects of DNA methylation and histone deacetylase inhibitors on human papillomavirus early gene expression in cervical cancer, an in vitro and clinical study. Virol J. 2007; 4:18.

96. Lin Z, Bazzaro M, Wang MC, et al. Combination of proteasome and HDAC inhibitors for uterine cervical cancer treatment. Clin Cancer Res. 2009; 15: $570-7$.

97. Yuan H, Myers S, Wang J, et al. Use of reprogrammed cells to identify therapy for respiratory papillomatosis. N Engl J Med. 2012; 367: 1220-7.

98. Feng D, Cao Z, Li C, et al. Combination of valproic acid and ATRA restores RAR $\beta 2$ expression and induces differentiation in cervical cancer through the PI3K/Akt pathway. Curr Mol Med. 2012; 12: 342-54.

99. Tsai C, Leslie JS, Franko-Tobin LG, et al. Valproic acid suppresses cervical cancer tumor progression possibly via activating Notch1 signaling and enhances receptor-targeted cancer chemotherapeutic via activating somatostatin receptor type II. Arch Gynecol Obstet. 2013; 288: 393-400

100. Coronel J, Cetina L, Pacheco I, et al. A double-blind, placebo-controlled, randomized phase III trial of chemotherapy plus epigenetic therapy with hydralazine valproate for advanced cervical cancer. Preliminary results. Med Oncol. 2011; 28 (Suppl 1): S540-6.

101. Hengstermann A, Linares LK, Ciechanover A, et al. Complete switch from Mdm2 to human papillomavirus E6-mediated degradation of p53 in cervical cancer cells. Proc Natl Acad Sci USA. 2001; 98: 1218-23.

102. Anchoori RK, Khan SR, Sueblinvong T, et al. Stressing the ubiquitin-proteasome system without $20 \mathrm{~S}$ proteolytic inhibition selectively kills cervical cancer cells. PLoS One. 2011; 6:e23888.

103. Stern PL, van der Burg SH, Hampson IN, et al. Therapy of human papillomavirus-related disease. Vaccine. 2012; 30 (Suppl 5): F71-82.

104. Miyamoto Y, Nakagawa S, Wada-Hiraike O, et al. Sequential effects of the proteasome inhibitor bortezomib and chemotherapeutic agents in uterine cervical cancer cell lines. Oncol Rep. 2013; 29: 51-7.

105. Pugh TJ, Chen C, Rabinovitch R, et al. Phase I trial of bortezomib and concurrent external beam radiation in patients with advanced solid malignancies. Int J Radiat Oncol Biol Phys. 2010; 78: 521-6.

106. Rice WG, Turpin JA, Huang M, et al. Azodicarbonamide inhibits HIV-1 replication by targeting the nucleocapsid protein. Nat Med. 1997; 3: 341-5.

107. Piccinini G, Foli A, Comolli G, et al. Complementary antiviral efficacy of hydroxyurea and protease inhibitors in human immunodeficiency virus-infected dendritic cells and lymphocytes. J Virol. 2002; 76: 2274-8.

108. Hampson L, Kitchener HC, Hampson IN. Specific HIV protease inhibitors inhibit the ability of HPV16 E6 to degrade p53 and selectively kill E6-dependent cervical carcinoma cells in vitro. Antivir Ther. 2006; 11: 813-25.

109. Zehbe I, Richard C, Lee KF, et al. Lopinavir shows greater specificity than zinc finger ejecting compounds as a potential treatment for human papillomavirus-related lesions. Antiviral Res. 2011; 91: 161-6.

110. Bruning A, Vogel M, Mylonas I, et al. Bortezomib targets the caspase-like proteasome activity in cervical cancer cells, triggering apoptosis that can be enhanced by nelfinavir. Curr Cancer Drug Targets. 2011; 11: 799-809.

111. Zhou J, LIU F, Xiao J. Recombinant adenovirus-p53 combined with chemotherapy in treatment of locally advanced cervical cancer (a phase II study). J Clin Oncol 2013; 31 (suppl): abstr5525.

112. Ashkenazi A, Holland P, Eckhardt SG. Ligand-based targeting of apoptosis in cancer: the potential of recombinant human apoptosis ligand 2/Tumor necrosis factor-related apoptosis-inducing ligand (rhApo2L/TRAIL). J Clin Oncol. 2008; 26: 3621-30.

113. Pukac L, Kanakaraj P, Humphreys R, et al. HGS-ETR1, a fully human TRAIL-receptor 1 monoclonal antibody, induces cell death in multiple tumour types in vitro and in vivo. Br J Cancer. 2005; 92: 1430-41.

114. Amé JC, Spenlehauer C, de Murcia G. The PARP superfamily. Bioessays. 2004; 26: 882-93.
115. Guggenheim ER, Ondrus AE, Movassaghi M, et al. Poly(ADP-ribose) polymerase-1 activity facilitates the dissociation of nuclear proteins from platinum-modified DNA. Bioorg Med Chem. 2008; 16: 10121-8.

116. Shunkwiler L, Ferris G, Kunos C. Inhibition of Poly(ADP-Ribose) Polymerase Enhances Radiochemosensitivity in Cancers Proficient in DNA Double-Strand Break Repair. Int J Mol Sci. 2013; 14: 3773-85.

117. Liu X, Luo X, Shi Y, et al. Poly (ADP-ribose) polymerase activity regulates apoptosis in HeLa cells after alkylating DNA damage. Cancer Biol Ther. 2008; 7: 934-41.

118. Diaz-Padilla I, Monk BJ, Mackay HJ, et al. Treatment of metastatic cervical cancer: future directions involving targeted agents. Crit Rev Oncol Hematol. 2013; 85: 303-14.

119. Hirai H, Iwasawa Y, Okada M, et al. Small-molecule inhibition of Wee1 kinase by MK-1775 selectively sensitizes p53-deficient tumor cells to DNA-damaging agents. Mol Cancer Ther. 2009; 8: 2992-3000.

120. Sgambato A, Zannoni GF, Faraglia B, et al. Decreased expression of the CDK inhibitor p27Kip1 and increased oxidative DNA damage in the multistep process of cervical carcinogenesis. Gynecol Oncol. 2004; 92: 776-83.

121. Singh M, Bhui K, Singh R, et al. Tea polyphenols enhance cisplatin chemosensitivity in cervical cancer cells via induction of apoptosis. Life Sci. 2013; 93: 7-16.

122. Di Domenico F, Foppoli C, Coccia R, et al. Antioxidants in cervical cancer: chemopreventive and chemotherapeutic effects of polyphenols. Biochim Biophys Acta. 2012; 1822: 737-47.

123. Franko-Tobin LG, Mackey LV, Huang W, et al. Notch1-mediated tumor suppression in cervical cancer with the involvement of SST signaling and its application in enhanced SSTR-targeted therapeutics. Oncologist. 2012; 17: 220-32.

124. Meyers JM, Spangle JM, Munger K. The human papillomavirus type 8 E6 protein interferes with $\mathrm{NOTCH}$ activation during keratinocyte differentiation. J Virol. 2013; 87: $4762-7$.

125. Bermúdez-Morales VH, Peralta-Zaragoza O, Madrid-Marina V. Gene therapy with cytokines against cervical cancer. Salud Publica Mex. 2005; 47: 458-68.

126. Bharti AC, Shukla S, Mahata S, et al. Anti-human papillomavirus therapeutics: facts \& future. Indian J Med Res. 2009; 130: 296-310.

127. Butz K, Denk C, Ullmann A, et al. Induction of apoptosis in human papillomaviruspositive cancer cells by peptide aptamers targeting the viral E6 oncoprotein. Proc Natl Acad Sci USA. 2000; 97: 6693-7.

128. Jonson AL, Rogers LM, Ramakrishnan S, et al. Gene silencing with siRNA targeting E6/E7 as a therapeutic intervention in a mouse model of cervical cancer. Gynecol Oncol. 2008; 111: 356-64.

129. Liu WL, Green N, Seymour LW, et al. Paclitaxel combined with siRNA targeting HPV16 oncogenes improves cytotoxicity for cervical carcinoma. Cancer Gene Ther. 2009; 16: 764-75

130. Zhou J, Li B, Peng C, et al. Inhibition of cervical cancer cell growth in vitro and in vivo by lentiviral-vector mediated shRNA targeting the common promoter of HPV16 E6 and E7 oncogenes. Antiviral Res. 2013; 98: 305-13.

131. Baleja JD, Cherry JJ, Liu Z et al. Identification of inhibitors to papillomavirus type 16 E6 protein based on three-dimensional structures of interacting proteins. Antiviral Res. 2006; 72: 49-59.

132. Beerheide W, Bernard HU, Tan YJ, et al. Potential drugs against cervical cancer: zinc-ejecting inhibitors of the human papillomavirus type 16 E6 oncoprotein. J Natl Cancer Inst. 1999; 91: 1211-20.

133. Beerheide W, Sim MM, Tan YJ, et al. Inactivation of the human papillomavirus-16 E6 oncoprotein by organic disulfides. Bioorg Med Chem. 2000; 8: 2549-60.

134. Liu Y, Liu Z, Androphy E, et al. Design and characterization of helical peptides that inhibit the E6 protein of papillomavirus. Biochemistry. 2004; 43: 7421-31.

135. Lehoux M, Fradet-Turcotte A, Lussier-Price M, et al. Inhibition of human papillomavirus DNA replication by an E1-derived p80/UAF1-binding peptide. J Virol. 2012: 86: 3486-500.

136. Van Pachterbeke C, Bucella D, Rozenberg S, et al. Topical treatment of CIN 2+ by cidofovir: results of a phase II, double-blind, prospective, placebo-controlled study. Gynecol Oncol. 2009; 115: 69-74.

137. Chaudary N, Pintilie M, Hedley D, et al. Hedgehog pathway signaling in cervical carcinoma and outcome after chemoradiation. Cancer. 2012; 118: 3105-15. 